\title{
Research on a simulation-based ship production support system for middle-sized shipbuilding companies
}

\author{
Young Joo Song ${ }^{1}$, Jong Hun $\mathrm{Woo}^{2}$ and Jong Gye Shin ${ }^{1}$ \\ ${ }^{1}$ Research Institute of Marine Systems Engineering, Seoul National University, Seoul, Korea \\ ${ }^{2}$ XINNOS, Seoul, Korea
}

\begin{abstract}
Today, many middle-sized shipbuilding companies in Korea are experiencing strong competition from shipbuilding companies in other nations. This competition is particularly affecting small-and middle-sized shipyards, rather than the major shipyards that have their own support systems and development capabilities. The acquisition of techniques that would enable maximization of production efficiency and minimization of the gap between planning and execution would increase the competitiveness of small-and middle-sized Korean shipyards.

In this paper, research on a simulation-based support system for ship production management, which can be applied to the shipbuilding processes of middle-sized shipbuilding companies, is presented. The simulation research includes layout optimization, load balancing, work stage operation planning, block logistics, and integrated material management. Each item is integrated into a network system with a value chain that includes all shipbuilding processes.
\end{abstract}

KEY WORDS: Production supporting system; Simulation; Value chain; Production planning; Process planning, Logistics.

\section{INTRODUCTION}

\section{Outline}

Recently, many new shipyards have been constructed, and there has been a strengthening trend within shipbuilding businesses. These new shipyards are trying to distinguish themselves from, and gain advantage over, their competitors through cost reductions, production system innovations, and by developing new ship types.

Many middle-sized shipbuilding companies in Korea have had trouble competing with BRIC (Brazil, Russia, India, and China) nation's shipbuilding companies, which are strongly competitive because of their relatively low costs and their governments' aggressive support. This competitive disadvantage in middle-sized companies is also related to their lower level of core management techniques when compared with major shipyards, such as those of Hyundai, Samsung, and Daewoo, which have their own system and development capabilities. The acquisition of such techniques enables maximization of production efficiency and minimization of the gap between planning and execution, both of which are required when attempting to increase a company's global competitive power.

Since the early part of the $2000 s$, Seoul National

Corresponding author: Jong Hun Woo

e-mail: jonghun_woo@xinnos.com
University and XINNOS have been conducting research into simulation-based support systems for ship production planning and ship production management (Shin et al., 2001; Woo et al., 2005; Woo et al., 2006). However, those researches lack of the strategic approaches, only concentrated on the virtualization of production system. For the advancement of digital shipbuilding methodology, a strategic approach is required which enables the coverage over the full shipbuilding processes.

In this paper, results of research into a simulation-based support system for ship production management that could be generally applicable to shipbuilding companies are reported. The research items included layout optimization, load balancing, work stage operation planning, block logistics, and integrated material management. In addition, each of the items has been integrated into a concept of network system with a value chain that includes all shipbuilding processes.

\section{Definition of the techniques of this paper}

The roadmap and its associated techniques used in this paper aim at the creation of an efficient ship production management support system for middle- and small-sized shipbuilding companies. The proposed techniques aim at increasing the efficiency of their production systems. The fundamental and key aspects of the proposed techniques are standardization of production data, integration of systems, optimization of information, and innovation within the 
production system. The scope of this paper includes all of the items required for, and directly related with, shipbuilding, and also those items correlated with production information systems, such as purchasing and ordering, design, construction method, and planning.

Production information, along with design, planning, materials, and blocks are standardized in a manner different from that in existing methodologies. Based on these new standards, the methodologies are constructed in order to optimize each relevant work-site operation. Also, advanced technologies, such as digital simulation, are utilized to obtain objectivity of results, and increase reliability, of the proposed system (Fig. 1). Fig. 1 shows a concept image of digital shipyard. Digital shipyard is non-tangible asset, which is differentiated from a physical tangible asset in the view of control and optimization.

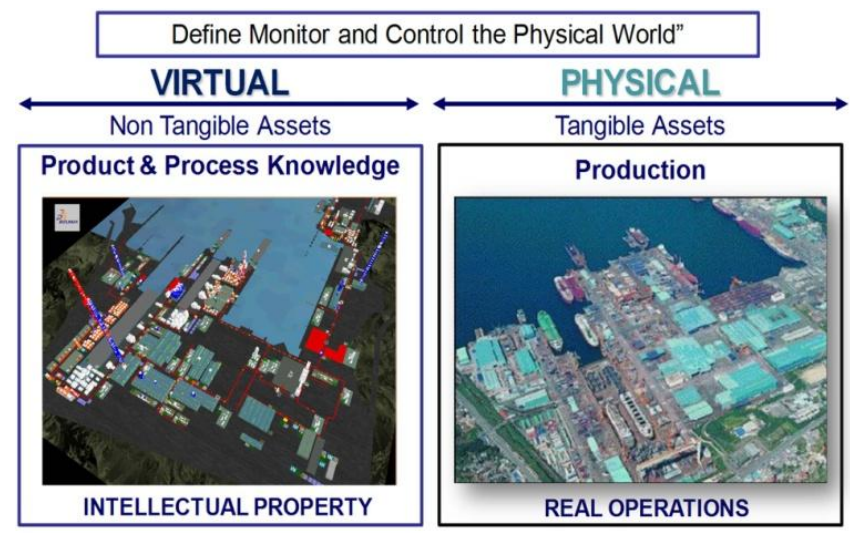

Fig. 1 Concept of a digital shipbuilding (Courtesy of DSME shipyard).

\section{Needs and objective of the techniques}

The target companies of this paper are middle- and smallsized shipbuilding companies and their associated shipping aids companies. There have been many such companies that have been unable to adapt rapidly to variation in their business surroundings owing to an absence of systematic production and a production management system. In particular, decreases in production progress caused by various kinds of delay events (drawing release delays, material ordering delays, material entering delays, processing delays, shortages of human resources, and planning errors) are a big issue.

Several strategies may be used to resolve the above problems. First, material shortages may be prevented by linking material ordering and material entering. Also, draw releases can be scheduled correctly by connecting production planning with design planning. However, these two linking strategy can only be available if the planning processes (master planning, erection planning, mid-term planning, etc.) are operated rapidly, accurately, and according to production needs (production planning, process planning and production management). Secondly, execution planning should be released from work packages that are linked with required material volumes after validation of their executability. Thirdly, capacity planning should be performed after adequate consideration of the gap between the activities planned and the record achieved. Lastly, production execution records should be checked with respect to all planning steps and this should be reflected in future planning.

For these proposed strategies to function, all distributed information related with production, such as design, purchasing, and planning information, should be standardized to the production viewpoint. Furthermore, the systems that analyze and generate the master data for the each stakeholder should be constructed, case by case, by linking the production value chain.

\section{LITERATURE REVIEW}

\section{Overseas Research Review}

BRIC nations, and others, are entering the shipbuilding industry with the help of low costs and their governments. For example, China, with its shipbuilding companies, such as the Dalian Shipbuilding Industry, Hudong-Zhonghua Shipbuilding, and Jiangnan Shipyard, is seen as a threat to the Korean shipbuilding industry. At the time of writing, there were about twice as many Chinese companies than Korean companies in the "Top 50" list of shipyards. Moreover, India is also expanding its shipbuilding industry and is planning construction of over 50 shipyards, the size of each is reported to be over 3 million square meters. Also, Vietnam and Singapore, countries that also have cost competitiveness, are entering into the world's shipbuilding industry.

Many of the LDDC (Least Developed among Developing Countries) are trying to introduce the newest technologies, such as three dimensional (3D) computer aided design (CAD) systems, enterprise resource planning (ERP) systems, and production management systems, in order to become competitive with countries that have advanced shipbuilding competitiveness, such as Korea and Japan.

Fig. 2 and Fig. 3 show examples of simulation-based planning support systems of German and Chinese shipbuilding companies, respectively. The Meyer Werft shipbuilding company of Papenburg, Germany has constructed a manufacturing information system (MIS) that can generate execution planning data when joined with a simulation package for pre-validation of their planning data (Fig. 2). The Yantai Raffles shipbuilding company of Yantai, China has adopted a 3D-based design system and a related product data management (PDM) system, and has become a pacesetting shipyard. Also, Yantai Raffles are going to develop a simulation-based production planning system which integrates with their 3D design and PDM system (Fig. 3). This will result in full coverage of their entire manufacturing production lifecycle management (PLM) system. 


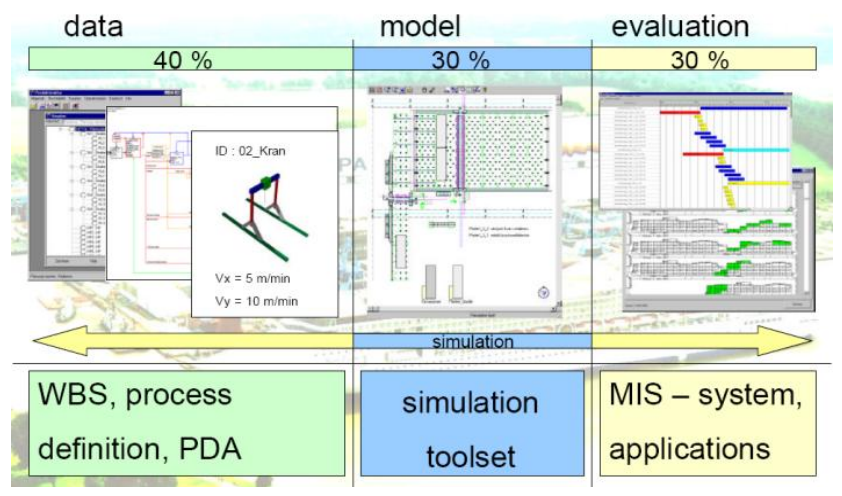

Fig. 2 Simulation toolkit for the production planning system of Meyerwerbt of Germany.

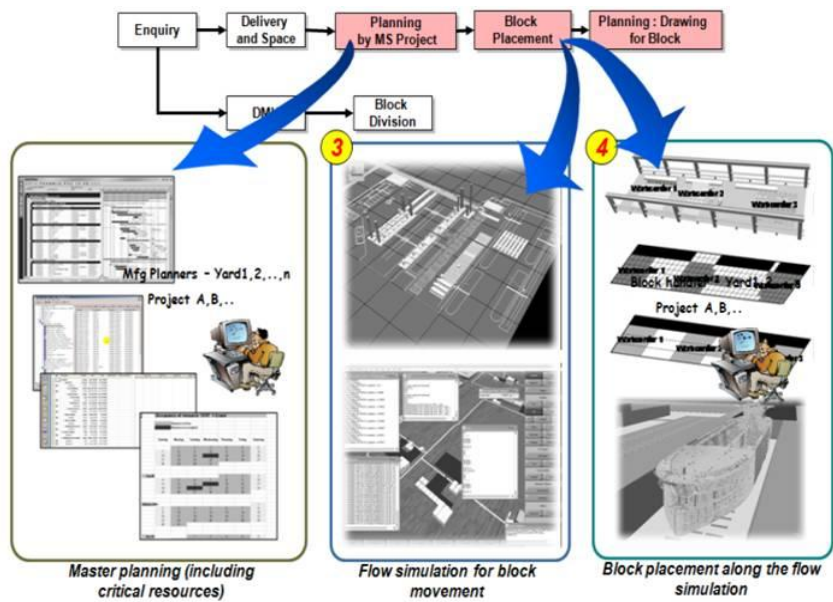

Fig. 3 Production planning system of Yantai Raffles Shipyard of China.

\section{Domestic Research Review}

Within Korea, there was a large nationally funded project into integrated production management systems, based on computer systems, called the 'CIM project', which was conducted by a consortium consisting of several domestic large shipbuilding companies at the late of 1990s. However, the overall integrated research project could not be performed even though a huge quantity of local research about production systems had been conducted, because the main concerns of each participating shipbuilding company were concentrated on their local requirements. Also at that time, the simulation paradigm was not seen as an important issue with respect to shipyard production management.

From 2001 to 2004, the nationally funded 'Integrated Digital Shipbuilding Technology for Development of High Value-added Ship' project was conducted by a consortium consisting of Seoul National University, Samsung Heavy Industries, and several national institutes. Through this project, research on ship production and shipbuilding simulation was widely performed; however, the results could not be put to practical use due to insufficient understanding by field workers of the new paradigm of simulation, as seen through implementation of a large shipbuilding computer model.

\section{SIMULATION BASED SUPPORTING SYSTEM FOR THE PRODUCTION MANAGEMENT}

The techniques proposed in this paper use simulation based methodologies that enable efficient and reasonable production planning and production management. The simulation definition used here is based on the PDS (PlanDo-See) Cycle (Fig. 4). This concept enables various topics those exist at actual shipbuilding company such as workload balancing, logistic optimization, erection process optimization, material ordering, material management, optimization of each production process, and integration of the value chain based on the ship table. Several topics are going to be handled in this paper.

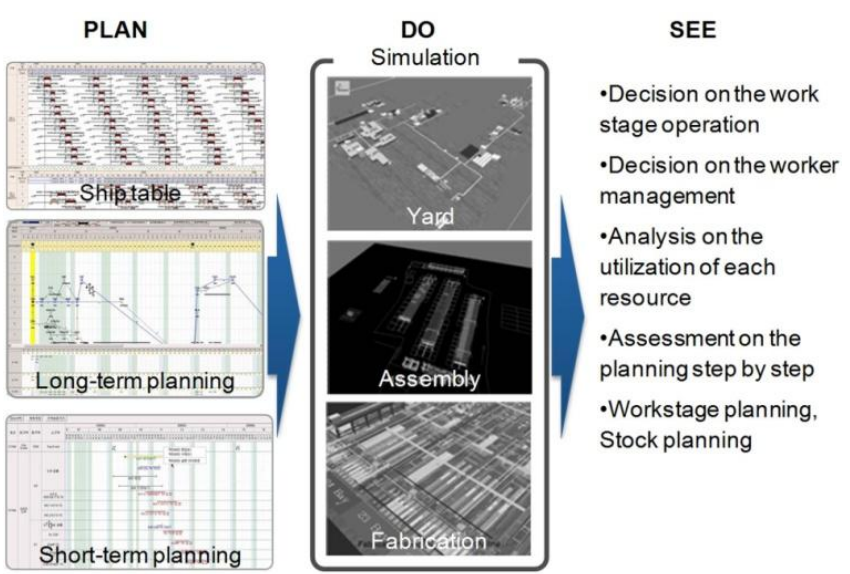

Fig. 4 Definition of the simulation approach to be used - PDS concept.

\section{DETAIL TECHNIQUES FOR THE SIMULATION BASED PRODUCTION MANAGEMENT SUPPORTING SYSTEM}

The techniques described in this paper are divided into two categories: foundation techniques and application techniques. Foundation techniques are specialized for, and specific to, the shipbuilding industry, whereas the application techniques are in accord with general and practical target development items.

\section{The foundation techniques}

\section{Data standardization}

In this paper, data is standardized to become full lifecycle data (i.e., from design through production to delivery) with emphasis on production. 
Deep understanding of, and investigation into, the work processes within each of the departments (design, production, planning, logistics, and material) that provide information, and detailed information on specifications, are required for data standardization based on a ship production viewpoint. Through these standardization efforts, the data are rearranged with respect to each process type within the ship production viewpoint.

Fig. 5 shows a case study of data standardization during the extraction of block assembly lead time, where the final standard lead-time with given block is calculated through the defined process.

There has been a case study about the data standardization for the construction of simulation system (Song et al., 2009), where block assembly data was combined as single template in the view point of ship production.

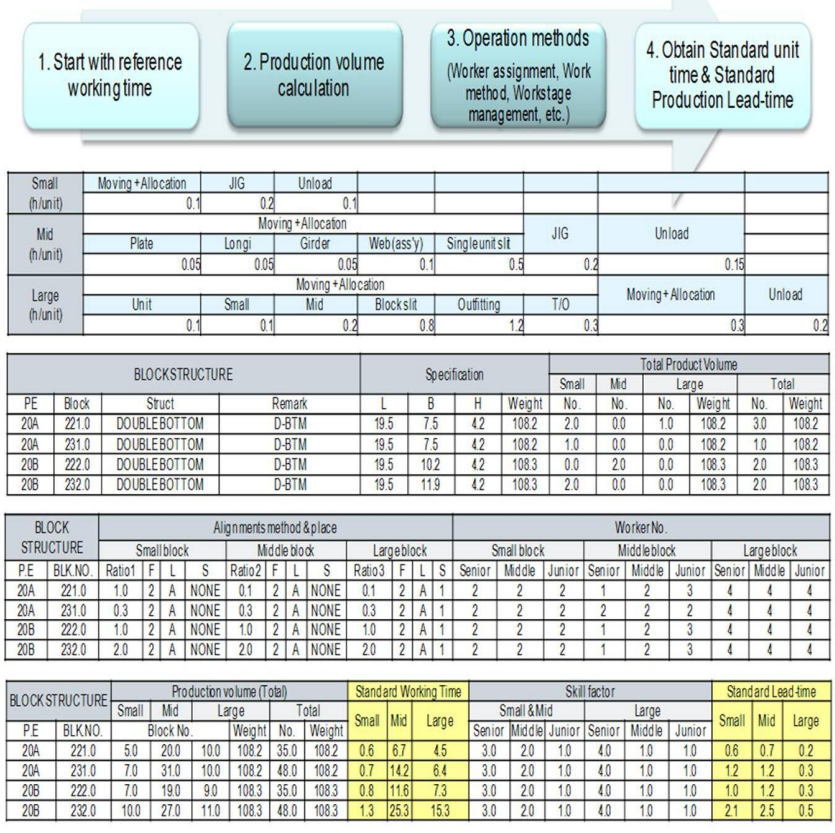

Fig. 5 Case study showing a standard processing time.

\section{Simulation technique}

The core of the simulation technique uses computer simulation aggressively. A simulation method is deemed necessary for critical decision making in the shipbuilding domain because there are numerous types and sizes of ships, which may be constructed simultaneously. In addition, there is wide variety in the types of production and in yard status, as well as variety within production methods.

A shipbuilding simulation method needs to be differentiated from traditional methods based on industrial engineering knowledge, because, traditionally, there has been little consideration of the frequency of variation in planning and production. Such variations are daily occurrences in the shipbuilding industry. Thus, expanded simulation techniques are needed in order to consider variation in planning conditions, as well as in products, production time, and production order. Fig. shows the results of several case studies of such shipbuilding simulations.

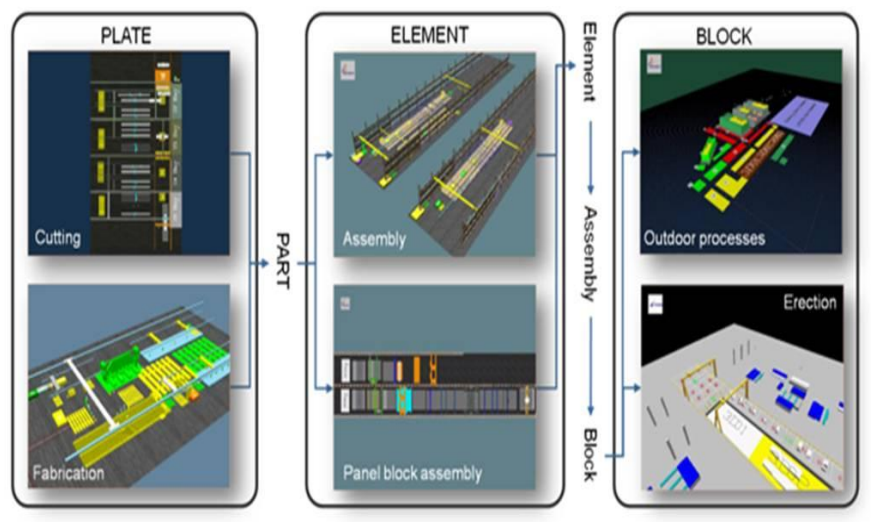

Fig. 6 Digital shipbuilding case studies.

\section{Optimization techniques}

There have been many attempts at shipbuilding optimization. However, those attempts have had limitations, many owing to their numerous assumptions. Such limitations are inevitable because the shipbuilding production system has a high level of complexity.

Table 1 Optimization methods with simulation.

\begin{tabular}{|c|c|c|}
\hline Method & Principles & Target \\
\hline $\begin{array}{l}\text { Linear } \\
\text { programming } \\
\text { with } \\
\text { simulation }\end{array}$ & $\begin{array}{l}\text {-Decision of the optimized value and } \\
\text { the status of the model after the } \\
\text { linear modeling considering } \\
\text { variables such as cost, lead time, and } \\
\text { material requirements that are } \\
\text { related linearly }\end{array}$ & $\begin{array}{l}\text {-Strategic decision } \\
\text { making about the } \\
\text { ship product mix, } \\
\text { factory operation, } \\
\text { worker planning, etc. }\end{array}$ \\
\hline $\begin{array}{l}\text { Simulated } \\
\text { annealing }\end{array}$ & $\begin{array}{l}\text { - Generic probabilistic meta heuristic } \\
\text { for a global optimization problem, } \\
\text { locating a good approximation to the } \\
\text { global minimum of a given function } \\
\text { in a large search space }\end{array}$ & $\begin{array}{l}\text {-Decision on the } \\
\text { sequencing order for } \\
\text { the maximization of } \\
\text { the resource } \\
\text { utilization }\end{array}$ \\
\hline $\begin{array}{l}\text { Genetic } \\
\text { algorithm } \\
\text { with } \\
\text { simulation }\end{array}$ & $\begin{array}{l}\text {-Converging into the most feasible } \\
\text { solution through repetitive } \\
\text { calculation with mutations of each } \\
\text { gene object }\end{array}$ & $\begin{array}{l}\text {-Combinational } \\
\text { optimization of the } \\
\text { planning } \\
\text {-2D layout } \\
\text { optimization }\end{array}$ \\
\hline $\begin{array}{l}\text { Nesting with } \\
\text { simulation }\end{array}$ & $\begin{array}{l}\text {-Allocation method that could utilize } \\
\text { the finite material of resource }\end{array}$ & $\begin{array}{l}\text {-Optimized block } \\
\text { allocation for the } \\
\text { maximization of the } \\
\text { utilization of each } \\
\text { work stage and the } \\
\text { stock area }\end{array}$ \\
\hline $\begin{array}{l}\text { No constraint } \\
\text { method based } \\
\text { on the } \\
\text { simulation }\end{array}$ & $\begin{array}{l}\text {-Generation of an optimized } \\
\text { combination of given resources and } \\
\text { maximum production capacity by } \\
\text { minimizing constraint conditions }\end{array}$ & $\begin{array}{l}\text {-Calculation of } \\
\text { feasible production } \\
\text { capacity } \\
\text {-Generation of the } \\
\text { production planning } \\
\text { at initial stage }\end{array}$ \\
\hline $\begin{array}{l}\text { Proximity } \\
\text { arrangement } \\
\text { based on the } \\
\text { simulation }\end{array}$ & $\begin{array}{l}\text {-Conducting of optimized mutual } \\
\text { arrangement by considering of } \\
\text { proximity and correlation factor. }\end{array}$ & $\begin{array}{l}\text {-Decision of the } \\
\text { resource location, } \\
\text { work center location, } \\
\text { etc. }\end{array}$ \\
\hline
\end{tabular}


Existing theories and practices have to be sublated during shipbuilding optimization in order for successful adaptation of the optimization method. Thus, the object of the optimization needs to be defined at an early stage in order to secure all of the information required for each target process. Also, optimization methods may have to be matched with individual work processes, such as for the generation of the routing information for a harmonious material flow, or for minimization of re-scheduling for efficient production planning. Table 1 shows an optimization methods and relevant targets. This table suggests a right method and its best target. The simulation engineer could graft a simulation technique with a best optimization method with this information.

\section{Application techniques}

The authors are going to describe several application techniques with given foundation techniques those are described in the previous chapter. Application techniques means that those can be applied to actual shipbuilding and planning processes from the material procurement to the production and process planning, and also operation management.

Construction of the integrated PO (Purchase Order) planning with the production and the integrated material management system

A general PO plan for shipbuilding is established based on design information, supplier information, and production planning. There can be serious problems in material procurement and material entering/carrying-out unless the location and the history of the material and its WIP (work in process) status are not traced correctly. These problems can result in excessive cost losses, related to material searches and additional transportation, if there is delay in postprocessing and material management. This is particularly true when one considers the size and weight of many ship components.

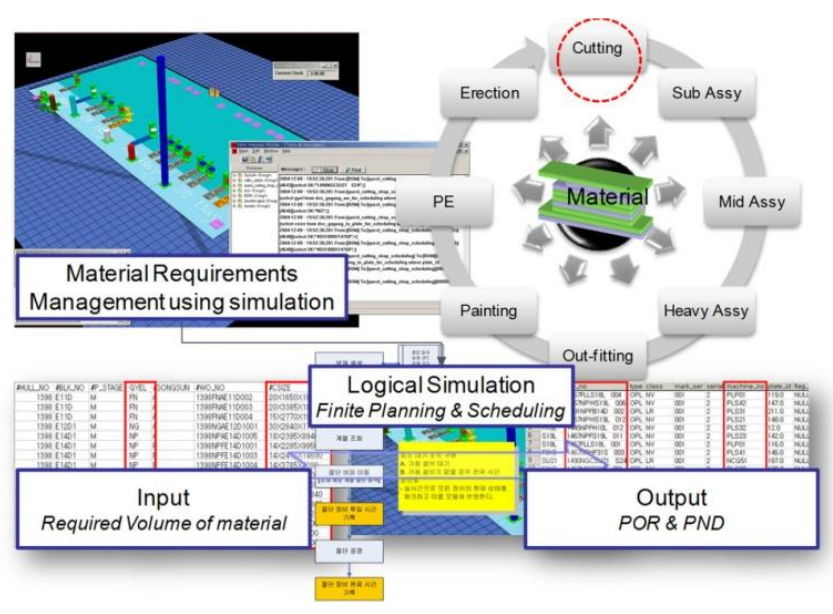

Fig. 7 Conceptual diagram of integrated material management based on simulation.
Here, integrating PO planning with production aims at JIT (just-in-time) material planning by tracing material flows that are related to execution planning. Briefly, this means that material procurement planning is generated from execution planning. This enables early consideration of material stock needs in relation to the detailed production process.

The simulation function plays the role of an engine within the order planning system and generates execution planning based on factory layout and production planning, and generates procurement planning based on material stock space and material requirement plans. For those purposes, the design and PO processes have to be connected with the material procurement procedure. Also, POR (purchase order requests) and PND (production need dates) should be generated using such simulations. Fig. shows a conceptual diagram of material management for cutting process. This diagram suggests a finite capacity based material management using simulation. The end user could plan a cutting process with given production volume within the finite capacity.

\section{Technique for the simulation based production planning system}

The general shipbuilding production planning process starts from the overall plan for the ship table. Subsequently, the ship table plan is broken down to show a capacity plan and mid-term plan. Lastly, these plans are further fractionized into short-term and execution plans. Brief descriptions of each planning phase are described in Table 2 Most shipyards have similar planning processes, but these specific planning procedures may be different depending on the needs of each shipbuilding company.

Table 2 Ship production planning.

\begin{tabular}{|l|l|}
\hline Phase & \multicolumn{1}{|c|}{ Contents } \\
\hline $\begin{array}{l}\text { Ship table } \\
\text { planning }\end{array}$ & $\begin{array}{l}\text { To determine the ship product mix, To } \\
\text { determine batch duration (dock rotation period), } \\
\text { To determine the main key-events of the each } \\
\text { planned ship }\end{array}$ \\
\hline $\begin{array}{l}\text { Long-term } \\
\text { planning }\end{array}$ & $\begin{array}{l}\text { Load distribution along the ship product mix of } \\
\text { the master planning, To determine the capacity } \\
\text { of the available human resources, To determine } \\
\text { the capacity of the facility type resources }\end{array}$ \\
\hline $\begin{array}{l}\text { Mid-term } \\
\text { planning }\end{array}$ & $\begin{array}{l}\text { To check or validate the master and long-term } \\
\text { planning, To schedule mid-term activities }\end{array}$ \\
\hline $\begin{array}{l}\text { Short-term } \\
\text { planning }\end{array}$ & $\begin{array}{l}\text { To check or validate the mid-term planning, To } \\
\text { schedule short-term activities }\end{array}$ \\
\hline $\begin{array}{l}\text { Execution } \\
\text { planning }\end{array}$ & $\begin{array}{l}\text { To analyze worker allocation, work flow, work } \\
\text { order, and output of the execution operation }\end{array}$ \\
\hline
\end{tabular}

These common planning procedures have their own problems, which can produce very complex work processes owing to the various constraints among and within the planning procedures and owing to the complex constitutions of various shipbuilding departments. 
This complexity problem may be resolved in top-level shipbuilding companies, such as Hyundai, Samsung, or Daewoo, because their information systems are well constructed. However, there have been problems with complexity in middle- and small-sized shipbuilding companies that do not have well established planning systems The absence of such a system may result in information disconnection and may weaken informational relations among departments.

The purpose of the simulation-based production planning system is to allow creation of planning data that is balanced and executable. Such a system relies on the use of standardized production data and computer simulation. In addition, such a system can transform planning activities from those with apparently infinite capacity to those with a finite capacity. Also, simulation-based production planning in shipbuilding supports multi-disciplinary decision making with its prediction function capabilities. Such simulations allow decisions based on production status and production time variations; aspects that are important in shipbuilding as there are large deviations in product size required processing times. Fig. 8 shows a schematic diagram of simulation based planning system. The simulation function is utilized as a planning case evaluation and optimization.

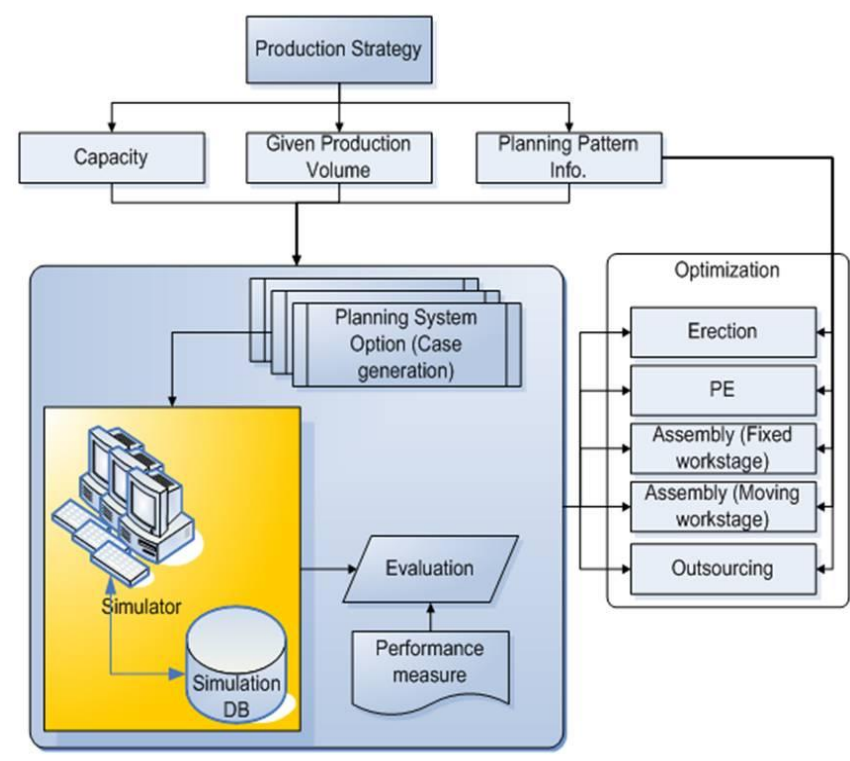

Fig. 8 Methodology for construction of a simulation based planning system.

Technique for the simulation based process planning system

The most important aspect of shipbuilding process planning is to decide on the order of the items to be accomplished during production. Production planning uses a process order for a given list of products (parts, blocks, etc.) while considering the available resource capacity over a given time line. Thus, the decision on a feasible work order sequence and a feasible insert order for the process planning plays a core role in the overall ship production.
In the similar way, within the production planning strategy described in 4.2.2, the consideration of a large deviation in product size and consideration of the required processing times over the required time line is critical during process planning. Accordingly, simulation-based process planning in an overall shipbuilding strategy should support multi-disciplinary decision-making and have a prediction function capability that can forecast product sequences and assess the feasibility of the production within a given sequence. Shin et al. (2004) have conducted a system construction project for supporting of sub assembly line of Samsung Heavy Industry. Fig. shows a concept for the process planning based on the simulation, where the overall required activities and information flow. With the simulation function, shipbuilding planner could optimize a process planning with respect to the planning boundary and the production capacity.

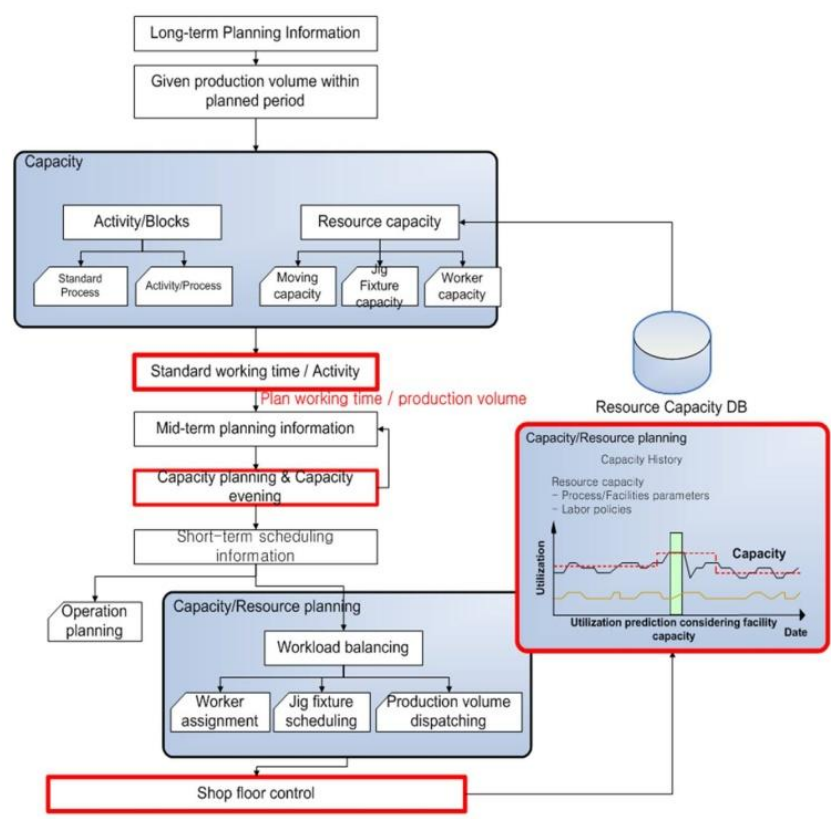

Fig. 9 Concept diagram of simulation based process planning.

\section{Technique for the simulation based integrated logistic planning system}

A critical point in the shipbuilding process is the logistics related to the ship block. In that part of the process, there could be production delays owing to disrupted material flow and confusion about the assigning of transportation resources. These kinds of problems should be checked during the planning phase. As a feasible solution for preventing undesirable ship block logistics, a simulation with a planning data input is useful because it could predict possible bottlenecks or overloads in material flow. Thus, a production planner could modify the planning results based on feedback from the logistic simulation. Such benefits have been achieved in other industries, such as automobile manufacturing, and automotive parts and module suppliers. 
Simulation-based planning in shipbuilding is seen as necessary because the time horizon and the physical scope of shipbuilding are very large, and there may be very large deviations in types and sizes of products. Fig. 10 shows a overall concept diagram for the shop block logistics based on the computer simulation. A similar case study about ship yard block flow simulation has been conducted (Song et al., 2009).

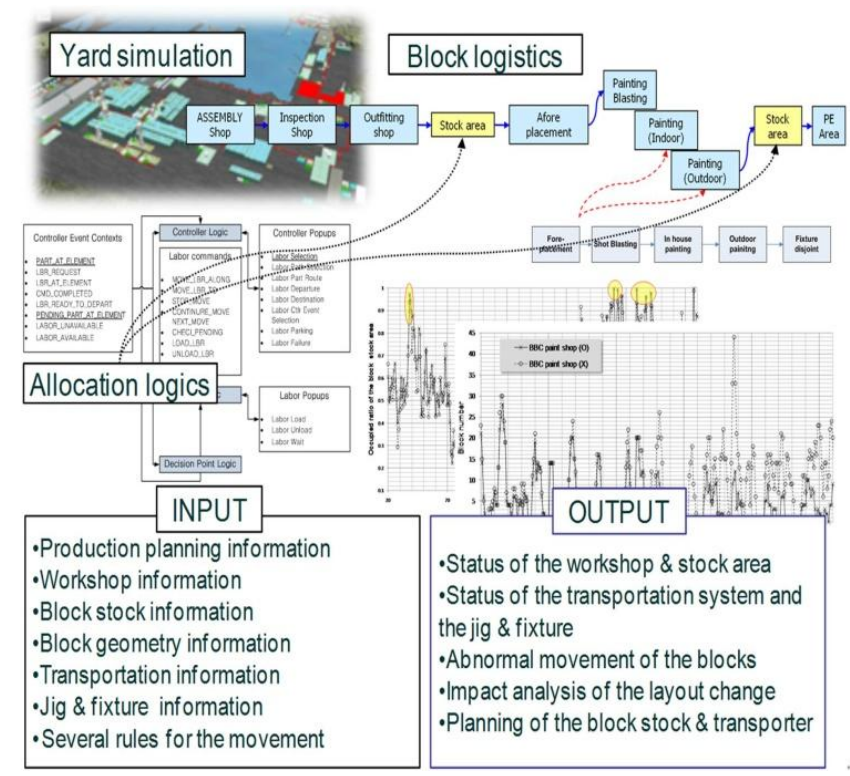

Fig. 10 Overall concept of the simulation-based ship block logistics system.

\section{Technique for the strategic value chain networking}

The strategic value chain is a core piece of information used for integration of work processes, such as strategy planning, master planning, and production planning, of a shipbuilding company, and is useful for the evaluation of the feasibility of the production strategy.

In that strategic value chain, the whole production process networking system is based on a master schedule that supports the long-term strategy and analyzes the production costs. This leads to generation of a simulation model that enables the analysis of a standard production process of a specific shipyard using measures of the shipyard's production capacity and resource capacity. In addition, using this simulation the work load at each production stage can be predicted by linking key events, such as purchasing, production, and delivery. Finally, operational strategies about the company's resource investment, stock planning, and buffer periods between each of the main production processes can be assessed by reviewing the future status predicted by the simulation. Fig. 11 shows a strategic value chain networking with simulation. The decision maker of a shipbuilding company could determine a strategic decision with proposed value chain networking because all the shipbuilding processes could be evaluated with respect to the given capacity and the other factors.
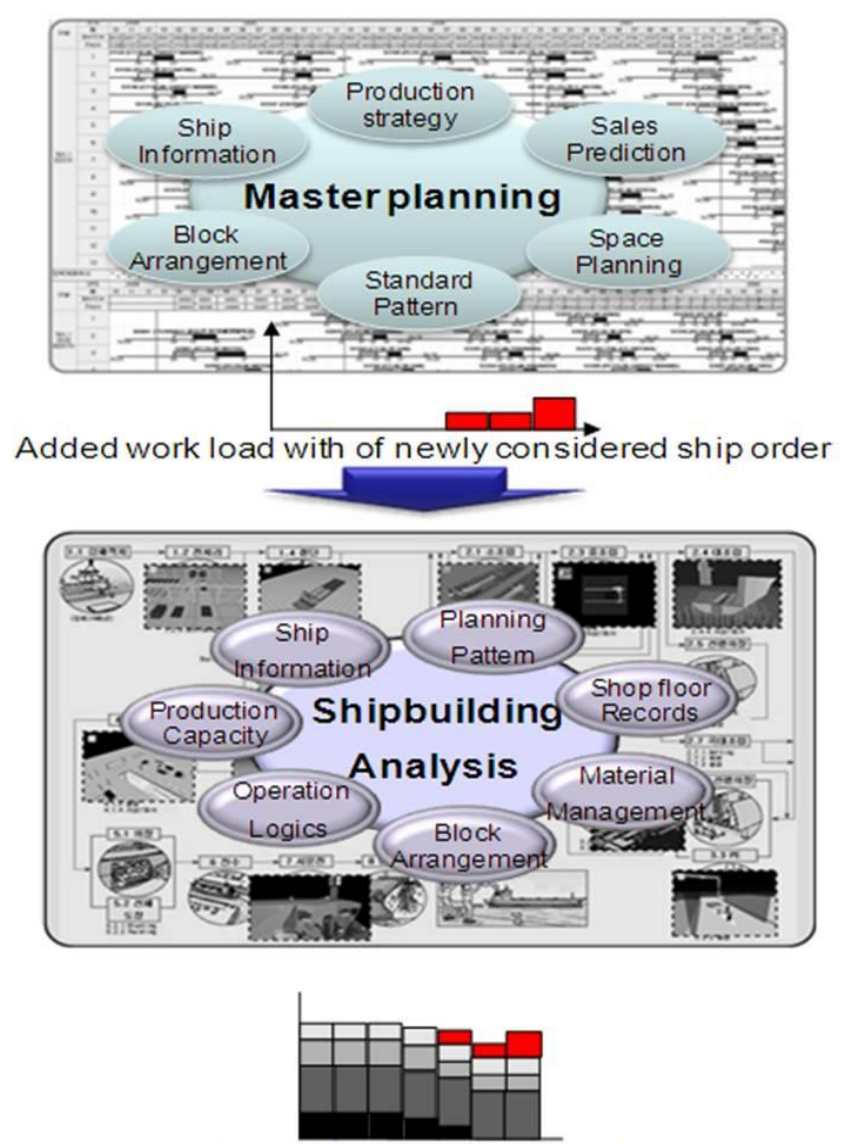

Simulation with the new ship order for all the connected shipbuilding processes

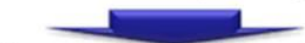

Fine an effect to total capacity
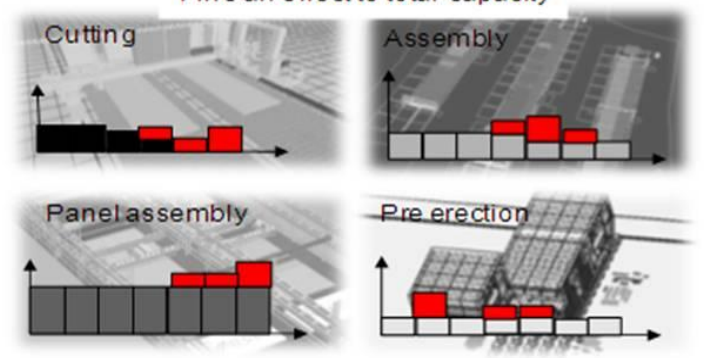

Fig. 11 Diagram of strategic value chain network.

\section{CONCLUDING REMARKS}

In this paper, research on a simulation-based support system for ship production management, which can be applied to the shipbuilding processes of middle-sized shipbuilding companies, is presented.

The simulation research including layout optimization, load balancing, work stage operation planning, block logistics, and integrated material management is presented. Also, this paper proposes that each item should be integrated into a network system with a value chain that includes all shipbuilding processes. 
This research could contribute to the strategic planning of middle-sized shipbuilding companies for their strengthening of competitiveness.

\section{REFERENCES}

Shin, J. G. Lee, J. H. Woo, J.H., 2001. Concept of the digital shipbuilding. Journal of the Society of Naval Architects of Korea, 38(1), pp. 54-62.

Woo, J.H. Lee, K.K. Jung, H.R. Shin, J.G. and Kwon Y.D., 2005. A framework of plant simulation for acc of a digital shipyard. Journal of the Society of Naval Architects of Korea, 42(2), pp. 174-183.
Shin, J.G. Lee, K.K. Woo, J.H. Kim, W.D. Lee, J.H. Kim, S.H. Park, J.Y. Yim, H.J., 2004. A modeling and simulation of production process in subassembly lines at a shipyard. Journal of Ship Production, 20(2), pp.79-83

Woo, J.H. Oh, D. K. Lee, K.K. Lee, C.J. Choi, Y.R. and Shin, J.G., 2006. Simulation modeling methodology and simulation system architecture for shipbuilding processes. Journal of Society of CAD/CAM Engineers, 11(1), pp1119.

Song, Y.J. Lee, D.K. Choe, S.W. Woo, J.H. and Shin, J. G., 2009. A simulation-based capacity analysis of a blockassembly process in ship production planning. Journal of the Society of Naval Architects of Korea, 46(1), pp. 78-86.

Song, C.S. Woo, K.Y., 2009. Journal of Society of CAD/CAM Engineers, 14(6), pp. 374-381. 